\title{
THE GREAT SCHISM: The Great Divide of the West, the East and Christianity
}

\author{
Anna M. Cox ${ }^{1}$ \\ ${ }^{1}$ M.A. in Political Science in American Government with graduate certificate in Ancient/Classical History from American \\ Public University, United States \\ Correspondence: Anna M. Cox, M.A. in Political Science in American Government with graduate certificate in \\ Ancient/Classical History from American Public University, United States.
}

Received: January 5, 2018

doi:10.11114/ijsss.v6i3.3024
Accepted: February 7, $2018 \quad$ Available online: February 12, 2018

URL: https://doi.org/10.11114/ijsss.v6i3.3024

\begin{abstract}
The historical tapestry of Medieval Europe was woven together with numerous profoundly influential threads. One of the most fundamental woven threads in the tapestry of this era was the thread of religion, the church and the Christian faith. An intrinsic part to this religious thread in the Medieval tapestry was the immensely profoundly transforming event of the Great Schism in 1054. The Great Schism in its own religious right was one of the most single profoundly fundamental and influential events that resulted in the transformation of a religion, culture and history. Moreover the Great Schism laid the foundation, paved the way and was the religious prequel of Martin's Luther's Protestant Reformation. Thus the Great Schism of 1054 had extensive, influential political, cultural, social, religious and historical consequences. The Great Schism's legacy of disunion would be evident in the church, the Christian faith and religion for many generations to come.
\end{abstract}

Keywords: Great Schism, The East (Greek), The West (Latin) 'Filioque', 'Eucharist', universal jurisdiction, papal primacy/supremacy

\section{Introduction}

In history each chapter and story have key moments or significant events that are set apart form all other that mold and alter the direction of the rest of that story and course of history. This was no less true during the Medieval Era in history. One of the most profoundly significant and defining aspects to Medieval culture and society was the facet of the church, religion and the Christian faith. Woven into the Medieval tapestry was the most significant thread of religion and church but within this most profound thread of religion was woven an immensely profound transforming thread of the Great Schism. The Great Schism in its own religious right was one of the most single profoundly influential and fundamentally transforming events that resulted in the transformation of a religion, a culture and history. Thus the Great Schism of 1054 had extensive, influential social, cultural, religious, political and historical consequences. It can be argued that one of the most influential and significant ramifications of the great Schism was the Protestant Reformation. In examining the Great Schism and its profound influence in the tapestry of religion, Medieval History and the world great consideration will be given to the understanding of Christianity, the journey that culminated in the Great Schism in 1054, defining the terms that were the foundation of the Great Schism, the division of the East and the West, the theological matters concerning the Great Schism, and the resulting lasting influential consequences of the Great Schism. It is through this extensive and comprehensive examination of the Great Schism that provides evidence of the Great Schism being the prequel and foundation for one of the most significant consequences of the Great Schism which was the the Protestant Reformation.

\section{Christianity the Religious Roots of the Great Schism}

In studying the Great Schism one must consider the religion and faith it is rooted in. In understanding the basis of Christianity one can gain insight into the Great Schism and the immensely fundamental influence of the Great Schism. As a religion Christianity is monotheistic in nature and thus is oriented around and founded on the worship of the one true God. Also Mitteraur expounds upon the foundation of the faith of Christianity in explaining that its a religion of salvation. The relationship of all the great salvific religions to the family ranges from ambivalent to critical. One aspect of this stance is individual justification. Salvation is a matter of an individual's act, not of the 'merits of the fathers'. 
And the individual cannot be charged with the 'signs of the fathers' Lineage is insignificant as far as the salvation of souls is concerned.(Mitterauer, 2003) Furthermore Appleby stats that the Catholic bishops' insistence of the unity and ones of God, creator and redeem, enshrined in the Nicene Creed, was the cornerstone of subsequent Christian doctrine. (Appleby 1998)

Also profoundly fundamental to the Christian faith is the Nicaea Creed of 325 which is the statement that embodies the essential core beliefs of the Christian faith. "I believe in God, the Father almighty, creator of heaven and earth; I believe in Jesus Christ, his only Son, our Lord. He was conceived by the power of the Holy Spirit and born of the Virgin Mary. He suffered under Pontius Pilate, was crucified, died, and was buried. He descended to the dead. On the third day he rose again. He ascended into heaven, and is seated at the right hand of Father. He will come again to judge the living and the dead. I believe in the Holy Spirit, the holy catholic Church, the communion of saints, the forgiveness of sins, the resurrection of the body, and the life everlasting. Amen." This creed and the beliefs that are established in this statement of faith would be front and center of one of the cornerstones of the Great Schism. Similarly it would be one of the sources of much division and strife between the East and the West as a result of the evolving interruptions of these points of doctrine and theology.

In combination with the paramount fundamental beliefs established in the Nicaea Creed and the expansive reach of the Christian faith had in Europe demonstrates the equally extensive profoundly significant influence the Great Schism had in the cultures, societies, politics of Europe, the church, the Christian faith, the history of religion and in the story and tapestry of Europe. Aside from the deep theological and doctrinal issues of the Great Schism Roberts explains that theoretically Europe had been entirely Christian since the dark ages. (Roberts 1993) Furthermore, articulated by Roberts, through the mid 1500s it was the Christian faith and church that united Europe. (Roberts 1993) Moreover Roberts discusses that religion was the one European tie and Christendom was an undivided whole, held together by a common faith and the work of the Church, Europe's single continent-wide legal institution. Church law operated in every land through courts alongside and separate from the lay system. All universities were governed and directed by churchmen. Finally, in every country the same sacraments were administered and imposed in the same pattern on the great events of people's lives - birth, marriage and death. (Roberts 1993) Thus it could be argued that to say that the Christian church united Europe is a paradox in terms for the Schism was nothing but a fundamental rift and division in the very same faith that united Europe True as that may be, one must understand that while there was a rift and strife in the Christian faith the idea of one faith is what caused Europe as a culture and society to be united for so long. Thus collectively between common beliefs, the faith and the extensiveness and expansion of Christianity is the very explanation and evidence as to why and how the Great Schism was such a monumental, profoundly, fundamentally influential religious event and chapter in church history and history itself.

Thus much of church history and medieval history following the Great Schism of 1054 was not left untouched, uncased, or uninfluenced which was more evident in the following centuries with the work of Marin Luther.

\section{The Religions Journey to the Great Schism}

In obtaining an understanding of the Christian faith that the Great Schism is rooted in thus one needs to give great and extensive consideration to the religious journey taken that culminated in the Great Schism. Although in 1054 what is know as the Great Schism ignited and exploded it was not just one thing that caused the Great Schism to erupt. Life and history is intricate, complex and multifaceted and is never about one thing but a series of interwoven things and events. Equally was the case for the Great Schism being the end result of a long complex and intricate journey of religious interwoven events. Thus a case could be argued that the beginning of the long religious journey began in 325 . Siegel discusses that the split between Eastern and Western Christianity came about slowly. In the year 325, the first ecumenical Council of Nicaea met to settle a few theological issues that were elusive, among them, the nature of the Holy Trinity. (Burnett 1997) Bromberg expounds on the initial stages and roots of the Great Schism by stating that the irksome controversy was the quarrel over Jesus' divinity. Trying to address a problem head on, according to Constantine, was not worth fighting over, he called for a council of bishops to resolve the dispute. There were even political reasons for holding the Great Council in his summer residence on Lake Nicaea. While Constantine leaned against Arius' position, even the social life over the course of the next five years despite having manipulated an anti-Arian statement of faith at Nicaea. The irritation within Christianity was not going away soon, and a great deal hung in the balance. According to Constantine, "Only a strong God, a strong church and a strong empire would provide helpless humans with the security they craved. (Bromberg 2000)

Another chapter in the journey of the Great Schism occurred during the Acacian Schism (484 - 519) which involved for the first time the West and East lining up against between Pope Hormisdas and Emperor Anastasius, Gelasius I. It was during this chapter that the seeds of universal jurisdiction and papal primacy were becoming evident. Blumenthal discusses the conclusion of these events of this religious journey which was to culminate in the dramatically stormy 
events that finally came to an end when Humbert, before his departure, deposited a bull of excommunications of the pariah and his supporters on the altar of Hagia Sophia. The fateful day was July 16 1054, long after the death of Leo IX. Humbert and his entourage left without having accomplished anything. As a synod was held the same month, Caerulagius in his turn excommunicated the Roman legates, designating them legates of Argyros. These events in the summer of 1054 initiated the schism between Roman and Greek churches.(UTA Renate Blumenthal 19888) In traveling along the journey that lead to the Great Schism one can see how and why the East and the West were divided, what divided them and what brought them to the point in 1054 of the Great Schism.

\section{Defining the Terminology of the Great Schism}

The third component relevant to the Great Schism in need of consideration is the fundamental, underlying terms and language that is the very foundation to the issues of the Great Schism. The word Schism in and of itself is defined as being a division or disunion, especially into mutually opposed parties. Although more particularly to this historical instance schism would be more specifically defined as a formal division within or separation from a church or religious body over some doctrinal difference. The first term that is a cornerstone of the Great Schism is in reference to the Holy Spirit, 'Filioque', which is defined as being the spirit of God, the presence of God as part of a person's religious experience. A second fundamental term is the language of the 'Eucharist', and it is explained as being the sacrament of Holy Communion, the sacrifice of the Mass or otherwise know as the Lord's Supper. Although more specifically the Eucharist involves consecrated elements of the Holy Communion, particularly the bread. A third essential cornerstone relevant to the Great Schism is the language of Universal Jurisdiction this term can be explained as possessing the right, power, or authority to administer justice by hearing and determining controversies, power; authority; control. Also this idea is defined as the extent or range as to which the law, judicial or other authority is exercised or implemented. This idea of universal jurisdiction was directly interwoven with papal supremacy. Thus the meaning explicitly implied by the lingo of papal supremacy is that the Pope or the office of the Pope was and had complete supremacy and supreme authority in all matter related to and involved in the church. These very religious and theological terms, issues and ideas are at the heart of the division that created and spurred on the the Great Schism between the East/Greek and the West/Latin.

\section{Insight into the Worlds of the Great Greek East and West Lain}

In examining the Great Schism consideration has been given to the basis of the Christian faith, the religious journey to the Great Schism, the fundamental terms of the Great Schism and as one continues forward with one's examination one would find it advantageous to consider the two diverse sides of the Great Schism the East/Greek and West Latin. In striving to understand these two very diversely different and varying cultures and societies one can gain much insight into the Great Schism and what drove these cultures and the church to the point of the Great Schism and why. Frazze states that it is key to realize that at the very outset and foundation of Christianity as a religion and faith that it was birthed into the area of the Mediterranean world where a division of cultures, Latin and Greek, deeply inherent and ingrained were at odds with the universalism of the faith. (Frazze 2007) Also stated by Frazze is that the reason and numerous others in Henry Chadwick's volume explains just how this caused Latin and Greek churchmen to quarrel over the centuries with the result that 'catholic; and 'orthodox' no longer had the same meaning, but defined two different churches. (Frazze 2007) Some of the inherent differences encompasses the difference in dominant linguistics on each side for in the East they spoke Greek and in the West spoke Latin. Furthermore as things continued to break down equally communication between the West and the East became increasingly strained. Dissolution in communication also created cultural disunity and thus lead to disunion in the church with the East and the West being aligned with their own cultural lines similar to the linguistic lines. As a religious consequence the West and the East each developed different religious rites and approaches to theological or doctrinal concerns and matters. All these differences between the East and the West came together to help pave the way and set the stage for the Great Schism.

As cultural barriers and language differences created deeper and more extensive division between the East and the West it was though these cultural and linguistic differences that the West and the East each developed their own religious rituals and practices that would create, only exacerbate and increase disunion and division. Mitteraur discusses that while there were no great doctrinal or theological differences between the churches of the West and the East regarding the sacraments however there were certainly much evidence of separation over the issue of administrating and receiving the sacraments. An example of this was that the East combined baptism as opposed to the West that separated out into baptism, first communion, and confirmation, according to one's age. (Mitterauer 2003) Holmes expands on these differences by discussing the orthodox contributed to and increased tension that developed between the East and the West from the ninth century. Amidst the more immediate factors which sparked off periods of schism were Roman claims to universal primacy, rival claims to jurisdictions over the newly converted area of eastern Europe, disagreements over ritual practices and the westerns' addition of the Filioque clause to the creed, and misunderstandings between individuals. (Holmes,1992) Understanding the differences between the East and the West one is given much 
insight to the Great Schism and sees the foundation of the Great Schism being laid thus setting the stage that would culminate in 1054 .

\section{The Theological Concerns of the Great Schism}

In the examination of the Great Schism there is a final component that is a cornerstone of the basis of the foundation laid for the Great Schism and that is the discussion of the various doctrinal matters of concern. It is most evident the split in the Church and the disunion in Christianity was caused by geographical, linguistic and political lines that were inflamed by a break in religious, theological matters. Among these theological matters that would become the cornerstones of the Great Schism was the Filioque/The Holy Spirit, the Eucharist and Universal jurisdiction or papal primacy/supremacy. These three matters of theological and doctrinal concern went to the very heart of Christianity, the church and the faith of the believer and would be the subject of much religious controversy.

\subsection{The Theological Concern of the 'Filioque'}

The first of the theological cornerstones of the Great Schism to be given much consideration is the doctrine of the Filioque or the "The Holy Spirit". Siegel states it was the matter of the Filioque that was the actual catalyst in 1054 of the Great Schism. (Burnett 1997)_Moreover Bromberg explains that it was the theology of the Filioque which 'healed' division a few centuries later caused an even greater one. The western and eastern factions of the church split in the Great Schism over the Filioque, that is, whether a line in the Nicene Creed would affirm that the Holy Spirit proceeds from the father and the son (Rome) or just the father (Constantinople). (Bromberg 2000) Furthermore Smith articulates that having the wording of the Filioque added to the creed affirms that the Holy Spirit "proceeds from the Father and the Son. (Smith 2014) Expounding upon this Siegel further states that later on the Western version of the Creed added a word, the single Latin word 'filioque' (ph), which means 'and the Son' So, the Western Church began teaching that the Holy Spirit proceeded from the Father and the Son, while the Eastern Church taught that the Holy Spirit proceeded form the Father. (Burnett 1997)

Although regarding this theological matter the Greek text of the Nicene Creed states the following: 'We believe in the Holy Spirit, the Lord and the giver of Life, who proceeds from the Father. With the Father and the Son, he is buried and glorified._He has spoken through prophets'. (Burnett1997) This would appear to be a simple and frivolous distinction but from a religious and doctrinal perspective for the East and the West it was no small thing. The doctrine of the Holy Spirit and from whom He came and followed dictated the form of worship, impacted the Eucharist and one could argue that even the issue of authority that would impact the religious thought of papal primacy/supremacy or universal jurisdiction. Smith states the following about the Filioque: "The Filioque ("and from eh Son") is the principal theological issue that divides the Roman Catholic and Orthodox churches, but it is more than a theological disagreement. The phrase is inserted into the creed commonly known as the Nicene Creed (more technically called the Niceno Constantinopolitan Creed a foundational creed for nearly all Christendom and an integral part of the celebration of the Holy Eucharist for many. Therefore, Smith states that altering of the pronouncement of an ecumenical council, the Council of Constantinople in 381, changed the worship of and life of the church.(Smith, 2014) In stating this Smith expounds and emphasizes this contentious theological point of the Filioque which was the most profound and immensely fundamental doctrinal influence in the Great Schism.

\subsection{The Theological Concern of the 'Eucharist'}

The second fundamental theological cornerstone of the Great Schism was the doctrine of the Eucharist and how the Eucharist should be administrated and received. Miterers explains that the sacraments of peace was individualized, restructured and made a requirement for receiving the Eucharist. The doctrine of transubstantiation helped establish the concept of the Eucharist as the Blessed Sacrament of the Altar, which lead to the interaction of the Feast of Corpus Christi. (Mitteraurs 2003) Furthermore Mitteraur expands on this by discussing the following on the Eucharist: "The belief in transubstantiation, and its concomitant forsook religiosity, uniquely transformed the concrete setting of the mystery of the Eucharist - the area around the church's altar and the objects appropriate to it. If we compare the function of gold in the Eastern and Western Churches, then we may say that he former used gold in the mosaics as the most worthy material for decorating the cupola - in keeping with the idea that a heavenly act was to be incorporated into the Eucharistic act. On the other hand, a Western goldsmith's highest achievement for the church was to provide settings, in the most dignified forms possible for the sacrificial offerings those substance had been transformed." (Mitterauer 2003)

A second component to this theological matter of the Eucharist was the issues of as to whether to use leaven or unleavened bread in the representation of the broken body of Christ during the administration of the elements in the holy sacrament of the Eucharist or Communion. Meyendoff explains that the consequence of this point of doctrine caused the East and West to equally either accuse the other of heresy or according the other side fall into heresy. After several centuries, liturgical differences came to be identified with differences of faith. Witness the cure debate between 
the East and the West in the 11th - 12th centuries over use of leavened or unleavened bread in the Eucharist. Both sides accused the other of heresy. Easterners, for example accused the West of rejecting Christ's divinity, symbolized by the leaven bread of the Eucharistic bread status. (Meyendorff 2002)

Naturally there was contention and religious controversy over these matters that continued to divide and split the East and the West. Frazee expounds upon and explains the differences in positions and the reactions of the East and the West to this matter. "Another issue of underling dispute was the proper bread for use in the Eucharist. The Eastern theologians charged that the Latin tradition of using unleavened bread, begun about 800, was terribly wrong. Byzantine extremists argued that unleavened bread might well make the Latin Mass invalid. It was over this charge that Michael Cerularius closed the western churches in Constantinople and in 1054 brought the Latin delegation to the capitol to see what could be done to have them reopened.

This date has since become the moment of the Great Schism in popular estimation. Of Course, chadwick knows this was not the case. Humbert of Moyenmoutier directed his excommunication against three people and their followers, no the whole Greek Church. He also holds that because the pope had died while his delegates were in Constantinople, they had lost their authority to act in his name.”. (Frazze 2007) In any case this gives evidence to the Eucharist being a fundamental and doctrinal cornerstone of the Great Schism that had much influential significance. Eucharist was influential to the point that churches were inclined and willing to accuse the other church and members of the perspectives church of charges of their form of worship and mass being invalid, heresy and excommunication from said church that was considered to be the right or a place of religious and theological authority. Thus resulting in the furthering and continuing of the division and breach in the Christian faith.

\subsection{Theological Concern of the 'Universal Jurisdiction or Papal Primacy/Supremacy}

The third and final fundamental cornerstone in the Great Schism and arguably potentially the one that was the most central thus the theological foundation and umbrella over all the other cornerstones is the matter of universal jurisdiction or papal primacy/supremacy. It is this single theological concern that relevant to the Great Schism the gives the strongest evidence for building the argument of the Great Schism bing the prequel to the Protestant Reformation. Frazze discusses how this cornerstone arose and became an issue by saying essentially the points of contention and problems that emerged between the West and the East are simple to comprehend. The Roman popes were convinced that their authority, as succession of Peter to whom Jesus had given the keys of the kingdom, extended over all other Christian communities when disputes arose. They were to have the last word on matters of faith, morality, and worship as 'head, mother and teach' of all Christians. (Frazze 2007) Moreover Woodrow expounds on this by articulating that the pope is first and foremost the center of unity of the church. To be Catholic (as individual, a bishop or a church) one must be in communion with the bishop of Rome. (Woodrow 1997) Appleby explains how this problem of universal jurisdiction/papal supremacy helped in bring about and contribute to the disunion between the East and the West. The Great Schism was irretrievably widened when Rome, acting sole on its own authority and without consulting the Eastern sees, added the Filioque to the Creed. Perplexed and aggrieved Eastern Christians, citing scripture (John 15: 26, where Jesus describes the spirt as. (Appleby1998)

There are numerous examples throughout the history of the pacy that exemplify and implement this belief of power and authority held by the pope. Blumenthal presents the example of Gregory applying and requiring absolute obedience to God and to himself as pope and as representative of the Apostle Peter. Gregory's self-identification with the prince of the apostles included his conviction that his papal actions were direct actions of Saint Peter himself. He argued that the recipients of his letters would hear in them the voice of Peter. (UTA Renate Blumernthal 1988)_Secondly Woodrow presents the position of Pope Leo I. Pope Leo I expounded upon the theory that would develop in the following centuries to come: As 'vicar of Peter', the pope has charge of the universal church, governing it as the emperors governed the empire. Gelasius I (492 - 496) went further. The 'apostolic see' while subject to no human tribunal, can judge each local church. (Woodrow 1997)

Similar to the fundamental cornerstones of the Great Schism the idea of Universal Jurisdiction / Papal Supremacy or Primacy contributed to the split between the East and the West. Woodrow explains that the West became 'papalist' while the East remained 'concilar'. The gradual decline - and fall in 476 of the Roman Empire freed the pope from the emperor's jurisdiction and consolidated his power. (Woodrow 1997) Furthermore Woodrow also states that the universal jurisdiction view was most certainly rejected by the Eastern church, for whom the pope is simply 'the first among patriots.'(Woodrow 1997) Thus in Greek Orthodoxy the Greeks, according to Frazee, were just as resolute to hold that Jesus transfer of authority was to all bishops who followed the apostles The pentarchy of the major sess, with Rome as 'elder mother' when united in the Spirit, formed a college of ecclesiastical leadership. The elder brother had no right to turn this office into an absolute monarchy. In the Greek Christian world, bishops were ranked according to the civic importance of their city. (Frazze 2007) Furthermore John explains the following:"From the Greek Orthodox 
theological point of view there was no need for and the reality of a universal head, that is, the bishop of Rome, can no longer be termed an exaggeration. If the Church is a universal organize, she must have at her head a universal bishop as the focus of her unity and die organ of supreme power. The idea, popular in Orthodox apologetics, that the Church can have no visible head because Christ is her invisible head in theological nonsense. If applied consistently, it should also eliminate the necessity for the visible head of the local church, i.e. the bishop.".(Richard 2008)

Thus according to Woodrow it could be argued that the sole gospel text to use the word church is Matthew 16:18. For many scriptural scholars this text means that Peter's primacy is one of service, not of jurisdiction. Thus nothing in the New Testament indicates that Peter was to have a successor. The early church was a loss federation of episcopal churches. Rome, together with Antioch, Alexanderia and Jerusalem, gradually became a reference in matters in faith. (Woodrow 1997) Therefore Woodrow describes the idea of Universal Jurisdiction or Papal Supremacy /Primacy or the inflated papal persona is also a serious stumbling block to Christian unity. The image of the pope as supreme authority in matters of doctrine and discipline, a media 'superstar' who occupies all functions and settles all disputes religious or secular, private or political, is hardly one to reassure Orthodox and Protestant Christians. Many would accept the spiritual role of the bishop of Rome as symbol of unity, but certainly not as absolute and infallible monarch leading a disciplined army. (Woodrow1997) In examining Universal Jurisdiction or Papal Primacy/Supremacy it is most evident how such points of view contributed to the Great Schism, caused and created much conflict, contention and disunity in the East and the West. Furthermore after extensive consideration of all the fundamental theological and doctrinal cornerstones there is much substantial and significant evidence to support each of them equally contributing to the division and disunity of the East and the West thus cumulating in 1054 with the Great Schism.

It is through this theological or doctrinal concern of the Great Schism that one can see how this was the prequel to Martin Luther's Reformation. One of the cornerstone of the Reformation was the idea of the Priesthood of the Believer which means a person who believed in Christ/believers no longer had to go through anyone wither it be a bishop or priest of whatever to get to Jesus or God. It could be argued that this theological thought or idea can directly be traced to the issue of universal jurisdiction or papal primacy/supremacy because as explain earlier the East argued that a power and authority did not solely come form one person or a figure such as the Pope. The East believed that no one person could be in the sole position to have complete and absolute authority of anyone or their faith. The authority and power could only come form God and Jesus alone. Thus Martin Luther took this idea a step further saying that it was up to the individual to go God and that it no longer required a person of divinity to intercede or allow a believer to seek God. The other piece that makes this case of the Great Schism being the prequel to the Protestant Reformation is that prior to the Great Schism no one would dare call into question the power, authority and position of the Pope to have and exercise such power and authority in all maters regarding the church, the faith and religion. Thus the papal primary or supremacy and the Pope having jurisdiction universally in all matters had just never been done before and was unthinkable. This opens up the door to the question had such ideas of universal jurisdiction and papal primacy/supremacy ever not began to be called into question during the Great Schism would there have been the the extensive of this by Martin Luther questioning further the power and authority of the Pope and the church by proposing the idea of the Priesthood of the believer. Moreover it could be asked if not for the Great Schism would there even had been the Protestant Reformation and never mind all the other furthering splits and division from the original church such as the Church of England and Calvinism. For it was with each of these continuing new religious thoughts and new sects that the church became more fractured, divided and broken form the original unified church of Catholicism. In extension of this the Catholicism was loosing more and more its power, authority and control of the people, culture and society. Therefore if this was first not called into question with the Great Schism would had it ever been called into questioned by anyone else after. If not then what of the Protestant Reformation, Church of England, Calvinism and countless others and the stage set for key world events would have never be set or done. In making this case based on this evidence it becomes profoundly evident that beyond a shadow of a doubt the Great Schism was the prequel that set the stage for the Protestant Reformation and so many other religious events that would further the great divide in the Christianity that all stem form the dividing of the East and the West starting the the Great Schism.

\section{The Comprehensive Influence Consequences of the Great Schism}

Considering the division and disunion between the East/Greek and the West/Latin, the terminology and language of the Great Schism and the theological or doctrinal concerns one can see vast evidence of the profoundly fundamental and immense comprehensive influence of the Great Schism. The core and the base of the Great Schism was rooted in faith and religious aspects of life which are often the base and foundation of any culture and society. Furthermore in the Medieval Era of history religion was the essential core of European society and as stated previously Christianity was the ties that bind. Certainly it was rooted in religion thus it influenced and changed the church, the face of Christianity and alter the course of the faith for the rest of history having the one church now and forever divided into the Catholic Church and the Greek Orthodox Church. Thus the religious consequences of the Great Schism in turned impacted the 
social and cultural aspects of Medieval Europe. Socially and culturally numerous things changed there were now present two churches and faiths, two sets of beliefs and ideals, and two sets of doctrines and theologies to ascribe to or follow. Also it was evident that there were now two interpretations of scripture and theology that created two ways of conducting and practicing of the sacraments and arguably two styles or fashions of how one was to worship and practice their religion. There cannot be division without consequence and specifically there cannot be disunion in a social and cultural institution without there being substantial and significant social and cultural ramifications as was evident by the Great Schism and by the fall out that resulted.

Also the Great Schism similarly had a major impact on politics during the Medieval Era. As a result of there being two social, cultural and religious sides present this created or inflamed the struggle for authority, control and power. Consequentially as a result the struggle for authority, power and control would be implemented by political leaders and there was extensive political conflict, battle for who would have power and who would have control in the East and the West over religion affairs and political matters. An excellent historical example that could arguably mirrored this were the Great Crusades during this era that were rooted and waged in the name of religion. Religion was simply the tool implemented to achieve the pursued goals of the quest for power and control. Also this idea of contention and power struggle in religion and the church could be steaming from and be rooted in the religious thought, one of the cornerstones of the Great Schism, of universal jurisdiction and or papal supremacy. There was conflict and dispute relevant to who had the authority to have the power to control the church and politics in Medieval Europe. There was no other piece of evidence that further that this was indeed the case then the Protestant Reformation which only fractured and widened the great divide in Christianity more profoundly.

A final area that the Great Schism had much profound influence was in the story of world history. The course of religion, the history of the Church and the world was forever altered and changed as a result of the Great Schism. Also it could be argued that another historical consequence of the Great Schism was the Protestant Reformation, Martin Luther's questioning of the Church and the Church's authority. Although it was a difference of about 500 years, it is as if the Great Schism opened the door and set a religious historical precedent of the idea of daring to defy, question and go against the church and what had been religiously established and ordained. Prior to the Great Schism while there were minor, small or here and there religious or theological spats and tiffs there had never been such a definitive, earth shattering, fundamental concrete division in the church and a breach of Christianity to the point that it broke communion and unity of the believers and of the collective church as the Great Schism created. It has been said it only takes one time, give an inch then a mile will be taken or the first cut is the deepest. Historically this very well could have been the case with the Church in the Great Schism for it was as if the Great Schism laid the foundation and opened the religious door of division thus leading the way to further religious disunion in the Church and the faith. Thus one of the historical legacies of the Great Schism could be paving the religious road to the Protestant Reformation and furthering the division more by all the Protestant dominations to come through the centuries, such as The Church of England or Episcopalian Church involving the England's split for Rome and the Catholic Church, that would be created following the Reformation. Thus the breach that the church, the faith and Christianity endured and suffered as a result of the Great Schism was never to be and thus has yet been healed and resolved with true and complete unity or oneness.

\section{Conclusion}

In examining the Great Schism extensively and most comprehensively much consideration has been given to several components comprising of the foundation and basis of the Christian faith, the religious journey to the Great Schism, the theological terminology and language of the Great Schism, the dividing differences between the West/Latin and East/Greek, the doctrinal and theological cornerstones of the Great Schism and the opposing and dividing positions of the East and the West. Throughout this extensive and intricate evaluation of the Great Schism numerous things have become most evident. Definitively the Great Schism was the great divider of the Church, the Christian faith and created disunion and a breach in communion in Christianity never to be truly healed and united. Also there would be all encompassing, most profoundly significant and immensely influential consequences that would be a direct result of the Great Schism such as political, cultural, social, religious and historical ramifications. The Great Schism altered and transformed the very course of the Church, the Christian faith and religion. This was demonstrates through Martin Luther's Reformation which lead toe the creation of the Church of England, Calvinism and numerous others. The true legacy of the Great Schism is of a complete breaking of the ties that bind and severing of the Church, creating disunion and division in the Christian faith to only leave the door open for future and greater chapters of religious dissection and disunion such as the Protestant Reformation, the origins of the Church of England, Calvinism and for all continuing division to come in future chapters in the church, religion and the church. The Great Schism left a religious, cultural and historical legacy to never be mended or resolved and an imprint of permeant religious disunion and division. 


\section{References}

Appleby, S. R. (Dec 1998). The Creed. U.S. Catholic 63.12.

Blumenthal, UTA- Renate. (1988). The Investiture Controversy: Church and Monarchy from the Ninth to the Twelfth Century. Philadelphia, PA: University of Pennsylvania Press 1988.

Bromberg, J. (Feb 4, 2000). Doctrinal murder and mayhem. National Catholic Reporter, 36(14).

Charles, F. (Sept 2007). East and West: The Making of a Rift in the Church from Apostolic Times until the Council of Florence. Church History, 76(3).

Holmes, G. (1992). The Oxford History of Medieval Europe. New York, NY: Oxford University Press.

John, B. (Jan 28, 1997). Eastern Orthodox NPR Washington D.C.

Meyendorff, P. (Jan - Apr 2002). Ecumenical prayer: An Orthodox perspective. The Ecumenical Review, 54(1/2). https://doi.org/10.1111/j.1758-6623.2002.tb00446.x

Mitterauer, M. (2003). Why Europe? The Medieval Origins and it's Special Path. Translated by Chapel, Gerald. Chicago, IL: The University of Chicago Press.

Neuhaus, R. J. (Dec 2008). Reconciling East and West. First Things, 18(8).

Roberts, J. M. (1993). A Short History of the World. New York, NY: Oxford University Press.

Smith, S. C. (Summer 2014). The insertion of the Filioque into the Nicene Creed and a Letter of Isidore of Seville. Journal of Early Christian Studies 22(2). https://doi.org/10.1353/earl.2014.0026

Woodrow, A. (Nov14, 1997). Inflated papacy is stumbling block to unity. National Catholic Reporter, 34(4).

\section{Copyrights}

Copyright for this article is retained by the author(s), with first publication rights granted to the journal.

This is an open-access article distributed under the terms and conditions of the Creative Commons Attribution license which permits unrestricted use, distribution, and reproduction in any medium, provided the original work is properly cited. 